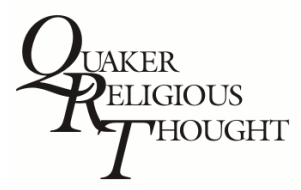

\title{
Quaker Religious Thought
}

2017

\section{Early Quakers and their Theological Thought, 1647-1723}

Paul N. Anderson

George Fox University

Follow this and additional works at: https://digitalcommons.georgefox.edu/qrt

Part of the Christian Denominations and Sects Commons, and the Christianity Commons

\section{Recommended Citation}

Anderson, Paul N. (2017) "Early Quakers and their Theological Thought, 1647-1723," Quaker Religious Thought. Vol. 128 , Article 4.

Available at: https://digitalcommons.georgefox.edu/qrt/vol128/iss1/4

This Article is brought to you for free and open access by Digital Commons @ George Fox University. It has been accepted for inclusion in Quaker Religious Thought by an authorized editor of Digital Commons @ George Fox University. For more information, please contact arolfe@georgefox.edu. 


\title{
EARLY QUAKERS AND THEIR THEOLOGICAL THOUGHT, 1647-1723
}

\author{
PAUl Anderson
}

\section{INTRODUCTION}

T $\mathrm{t}$ is with great appreciation to the authors and editors of this Limportant volume on the theological thought of early FriendsStephen Angell and "Ben" Pink Dandelion-as it fills a gap in the history of Quaker research in much needed ways. While the social histories, political concerns, spiritual interests, and social-action contributions of early Friends have been explored extensively, and while the spiritual experience and the theological contributions of some standout leaders have been explored, the theological convictions and contributions of key Quaker leaders has not been amassed as a collection until now. That being the case, this book stands as a valuable companion to the first-rate collection gathered by the same editors in 2013, The Oxford Handbook of Quaker Studies.

I proceed now to engage the introductory essay by Douglas Gwyn and those of four others.

\section{"SeventeEnTH-Century Context AND Quaker BEGINNINGS" BY DOUGLAS GWYN}

Doug Gwyn's introduction to the project sets the contextual stage for understanding Quaker beginnings in the 17th century. On epistemology and eschatology, Friends believed they had entered a new age in which the spiritual vitality of primitive Christianity would be revived by the irruptive work of Christ, through the Holy Spirit, as the Lamb's War is the only effective advance upon the ways of the world, over and against political platforms and polemics.

On hermeneutics and ecclesiology, it is the gathered community of Christ that partners together with God in the social transformation of the world-operating by the way of Christ's kingdom rather than against it. On Christology and pneumatology, the work of the light of Christ within, through the witness of the Holy Spirit, transforms the 
individual in the liberating power of truth. Despite human fallenness to $\sin$ ( hamartology), the perfecting power of the Holy Spirit avails the convinced believer not only the power to overcome the penalty of sin; it also extends one the power to overcome its grip (soteriology).

On cosmology and ethics, a vision of the world transformed by Christ was elevated by George Fox and others, and it served as a challenge to the dominant social and religious norms of the day. Therefore, the entire world is the focus of apostolic mission, and all of life is a testimony to the workings of Christ within and among his followers. Gwyn also argues that the discerning, synthesizing, and signifying work of Fox played a key role in the influencing of other Quaker leaders - a reality to which the following fifteen essays bear witness.

In appreciation of this essay, it offers a very helpful and nuanced window onto the times out of which the early Quaker movement began. A question I might raise involves the degree to which the biblically oriented vision of George Fox and other early Quaker leaders might have been formed by their understandings of "Primitive Christianity" and experiences of "visitations of the Spirit" in the development of their convictions and witness.

\section{“The Conventionality of the Notorious John Perrot” by Carla Gardina Pestana}

In her essay on the notorious John Perrot, Carla Gardina Pestana reviews the controversial life of John Perrot, inviting empathy as well as understanding. The Irish Baptist had become a convinced Friend in response to the ministries of Francis Howgill and Edward Burrough. Readers will be familiar with basic elements in Perrot's story, although this treatment adds a new analysis. Perrot is remembered for the second of Quaker controversies, following the embarrassment of the Nayler incident, but there's more to the story.

Indeed, Perrot set off on a missionary journey to testify against the Pope at the Vatican along with John Luffe and others in 1657; while Luffe was hanged in the Inquisition, Perrot was imprisoned for three years in an institution for the mentally insane. Following his release, Perrot rejoined Friends in England as something of a hero. His controversy among Friends, then, centered upon his refusal to remove his hat in honoring George Fox. On one hand, this could be seen as an issue of hat-honor. Gradina Pestina, however, points to 
EARLY QUAKERS AND THEIR THEOLOGICAL THOUGHT, 1647-1723 • 21

the issue as being a matter of conscience for Perrot. If Quakers were known for treating all people with equality before God, should this not also apply to the treatment of other Quakers-including George Fox? On this matter, the present analysis argues that the issue was one of conscience.

As a result of Perrot's public defiance of George Fox's personal authority among Friends, Perrot was disparaged among Friends, despite continuing in his preaching and pamphleteering ministries. He therefore retired to Barbados, where he ministered with some esteem despite his disparagement by some leading Friends. While he hoped for reconciliation with Fox, it never came, and he died in Jamaica in 1665. Interestingly, the Perrot controversy was a result not of failing to live up to Quaker principles; it was the result of applying them consistently to leading Friends as well as to others. On this matter, Perrot might have found a more conciliatory means of expressing his conviction, but his seeking to mind the Light is what got him into trouble, showing that consistency can be every bit as much of a problem as inconsistency in applying Quaker testimonies within the Quaker camp as well as outside it.

This essay by Gradina Pestina describes the issues clearly, and one question I might ask relates to why George Fox himself was not more conciliatory toward Perrot. Why, for instance, did Fox not welcome the challenge in good humor and affirm the attempt at egalitarian action instead of allowing it to cause alienation? That could be a profitable inquiry.

\section{"Felt Reality in Practical Living and Innovative Thinking: Mary and IsaAC PENINGTON's JOURney From Puritan Anguish to Quaker Truth" by R. MELVIN KeISER}

In this essay on the theological contributions of Mary and Isaac Penington by Mel Keiser, the felt reality of their religious experiences and beliefs are shown to have made great contributions by their lives and in their writings. As an aristocratic couple, they also became leading spokespersons for the Quaker movement, showing "how to pursue wisdom on a Quaker path." Their convincement came as a result of encountering a Quaker whose witness to the Light of Christ led them to encounter the transformative presence of God in their own lives, and they joined the movement in 1658 . 
Following the death of her son and first husband, Mary joined Isaac in marriage a decade or so later. Within the Quaker movement, she advocated the leadership of women through Women's Business Meetings, and her daily quest for divine guidance became a model for living the Quaker way within domestic situations. Her book on everyday life, Experiences in the Life of Mary Penington, was not published until 1821, so her broader impact upon Friends and others was delayed until nearly a century and a half after her death. In sharing about her dreams and how God spoke to her personally, Mary Penington contributed powerfully to the spiritual formation of later readers. In recording three archetypal dreams-seeing a book of hieroglyphics in contrast to a bright light, the bride of Christ (the church) as a female partner to the Lamb, and a vision of the Last Supper in the upper room-images of the relationship between Christ and his true followers are conveyed. These dreams characterized her Puritan and Quaker convictions regarding the simplicities of life and the power of the human-divine relationship and its ensuing fellowship.

Having encountered a spiritually transformative encounter with Christ, Isaac Penington's religious experience developed theologically a set of understandings regarding how God works within the life of the individual in ways that bring newness of life and continuing guidance. Expanding on the image of "seed" as a means of describing the work of Christ within, Isaac contributes significantly to an emerging Quaker Christology, wherein the active workings of Christ within the life of the individual create a new existence. As a leading innovator in emerging Quaker theology, Isaac explores the meaning of biblical metaphors for God's work within the life of the believer, expanding also upon impressions of the human-divine relationship emerging out of silence in worship. "Salvation for Isaac was dwelling in and living from the Spirit of eternal Christ within." (p. 203) In the victory of the dualistic good over the evil, sanctification and perfection are possible, and a true Christian is one in whom the "new Creation" through Christ is availed.

Keiser's essay makes a valuable contribution to Quaker and theological studies more generally, in that it shows the dynamic leadership given by an early Quaker couple in ways that feature both of their experiences and contributions, distinctive though they be. One question I might raise regards the degree to which the imagery in both of their christological understandings of God's saving-redeeming work might make an impact upon Quaker and broader theological reflection, as well. 

S. PYPER

In this fine essay by Hugh Pyper, the importance of Robert Barclay's Apology for the True Christian Divinity in 1676 (Latin) and 1678 (English) is assessed within its contextual and contemporary settings. Given young Robert's first-class theological education in France, and following the lead of his father in becoming a Quaker, his Apology is theologically systematic without being a systematic theology in the disciplinary sense of the term. Unreflective critics need bear this in mind, as modern theologians well versed in how theology is done within a particular "school" might miss the larger importance of his work. In that sense, Barclay is not simply seeking to levy a theological treatise to inform theologians within a guild. Rather, his apology for "the true Christian divinity" sets out to explain how the heart of Christian certainty and infallibility is found within relational knowledge of God, not simply knowledge about God-as Quakers had been claiming is the heart of Christian faith and practice-knowing God and the one sent by God, Jesus Christ (John 17:3).

While Barclay sought to bring the entire world to the convincement of truth (a reference to the work of the Holy Spirit within, John 16:811), he had in his sights a more particular target: the Calvinism of Scottish and European society, which he sought to counter without becoming vulnerable to suspicions of Pelagianism, Socianism, or Arminianism. Pyper elucidates this rhetorical thrust by contrasting the subtitles of the Westminster Catechism of Faith with Barclay's earlier publication in 1673. Over and against "The Confession of Faith: Agreed upon by the Assembly of Divines at Westminster, with the Assistance of Commissioners from the Church of Scotland," Barclay's treatise was entitled "A Catechism and Confession of Faith, approved of and agreed unto by the General Assembly of the Patriarchs, Prophets and Apostles, Christ himself Chief Speaker in and among them." In his Apology to follow, Barclay sought not to lay out the planks in a Quaker sectarian platform; he sought to advance a defense of authentic Christian faith and practice: rooted in Scripture, the Apostolic Fathers, and the best of human reason.

In his treatment of Barclay's approach, Pyper notes several themes and thrusts of the Apology, which is still the most definitive of Quaker theological treatises, although Gurney's Peculiarities comes close in its quality and scope. In building on Augustine and Descartes, Barclay adds to the self-sufficiency of reason the universal awareness of sin and 
the need for God. Like geometry, true knowledge of God is infallible in itself, and yet it is known relationally and experientially, rather than cerebrally and intellectually only. Therefore, God's gospel truth is eternal, but its expression and apprehension are temporal-contingent upon time-bound communications and receptions. Christ as the Light and "Seed," operative within the experience of the believer, thus enables the transcendence of human depravity, leading to the possibility of perfectibility. Therefore, one must be open to one's "Day of Visitation," responding to it in faith. That is what constitutes the true church, and as believers come into the holy assemblies of God's people, evil is weakened, and the good is raised up-empowered by the transformative work of the Holy Spirit in their lives.

Barclay's Apology commanded an unparalleled impact upon the religious thought world of his day, and yet its import was marginalized by non-Friends. Some saw it as merely as a sectarian document, while others diminished its value because it was something outside of the genre of standard treatments of a systematic theology. In speaking powerfully to the issues of his day, however, Barclay laid out a compelling defense of the priority of experiential and transformative knowledge of God as the basis for true Christianity. If someone were to write a parallel treatise addressing today's needs, I wonder if something like an apology for authentic spirituality might fill the bill. Come to think of it, that's been done. ${ }^{1}$

\section{"Elizabeth Bathurst: 'Tis Not Inky Character Can MAKe a SAINT"” BY MARY VAN Vleck Garman}

Lest it be assumed, however, that all early Quaker theologians were men, the treatments of Dorothy White and Elizabeth Bathurst in this volume, in addition to the Peningtons, show a different story. In the fine collection of Quaker women writers, Hidden in Plain Sight, Mary Garman and her co-editors have gathered an extremely helpful collection of theological writings, and within that collection, the work of Elizabeth Bathurst is featured as a theological treatise on a comparable order to the works of Robert Barclay. ${ }^{2}$ Though she only lived thirty years, Elizabeth Bathurst traveled in ministry, preached, and wrote as a public minister among Friends; thus, her legacy continues as a factor of the recent interest in her newly featured writings. She became convinced of the truth when two traveling Friends ministers spoke in her home, and she became involved in public ministry soon 
EARLY QUAKERS AND THEIR THEOLOGICAL THOUGHT, 1647-1723 • 25

thereafter. George Fox even records in his Journal that he had heard her preach, and that he had visited her home.

Best known for her published works, her first piece was $A n$ Expostulary Appeal, challenging the Presbyterian doctrine of "the elect few." In her faithful exposition of the biblical witness, Bathurst developed the theme of God's universal love for the entire world, but it was delivered in oral form only after the conclusion of the worship service. In response to a harsh reception, she pointed people to Christ, who himself is truth, and called for them to turn to Christ inwardly in order to receive the gift of saving grace.

Her second published work is her best known: Truth's Vindication, in which she offered her own apologetic defense of the Quaker faith. Part I addresses slanders against Friends, including claims that Quakers were less than biblical, that their Christology was inadequate, that their sacramental views were unbiblical, that their doctrine of sin was off, and that their message of God's universal love was flawed. In so doing, she exposited the Scriptures ably, showing from both biblical teachings and examples the biblical and experiential adequacy of Quaker faith and practice. Part II continues these claims by means of personal testimony, showing how her inward experience with the truth of Christ led to transformative spiritual encounter and empowerment. Here she expands upon Barclay's theme of one's "Day of Visitation," exhorting all to respond faithfully to the free extension of God's grace in Christ, availed by his saving-revealing work. Part III picks up again the false accusations against Friends, and here she challenges directly five Presbyterian friends to receive in charity what she had written in humility.

Bathurst's final text, The Sayings of Women, developed the biblical accounts of God's Spirit being poured out on the whole household of Israel, including young and old and women as well as men. With such female heroes of the Bible such as Sarah, Rachel, and Leah performing important roles in the history of Israel, in addition to unnamed women, these biblical examples of faith and courage point the way for later generations to follow. Likewise in the New Testament, Jesus' healing of the woman in Mark 5 and his encounter with the Samaritan woman in John 4 show that Jesus reached out to women in his ministry, and their important roles in leadership continue in the Acts of the Apostles and the writings of Paul. Central is Paul's conviction that in Christ there is neither male nor female; in Christ, enmity between religions, races, and genders is eschatologically overcome. 
As a female theologian, Elizabeth Bathurst commands great interest for modern readers, as her newly discovered works are explored and appropriated. Exegetically, her getting to the core of a biblical text's meaning poses an exemplary approach to existential hermeneutics; theologically, her integration of biblical content with human experience points the way forward in ways both reasoned and relevant. Mary Garman does a great service in this essay, not only to a helpful understanding of Bathurst's works, but she also poses a great exemplar for contemporary feminist, womanist, and other hermeneutical studies, as well. A question I might raise here would be to ask whether a fuller analysis of Elizabeth Bathurst's hermeneutical method might be of service to cognitive-critical biblical analyses today.

\section{CONCLUSION}

Again, the four essays here described and engaged are all excellent and first-rate in their insights and expressions. Not only will Quaker readers be helped in consulting them, but so will all interested in biblical, theological, religious, spirituality, historical, feminist, and existential studies. I commend the editors and the authors for this fine collection, as now a fuller sense of early Quaker theology is available to readers and all seekers of the truth.

\section{ENDNOTES}

1. Paul Anderson, “An Apology for Authentic Spirituality,” QRT 114 (2010): 20-37.

2. Hidden in Plain Sight: Quaker Women's Writings, 1650-1700, Mary Garman, Judith Applegate, Margaret Benefiel, Dortha Meredith, eds. (Wallingford, PA: Pendle Hill Press, 1996). 